\title{
Ensuring The Right of The Suspect And The Accused For Defense
}

\section{Garantizar el derecho de defensa del sospechoso y del acusado}

\author{
Anton Valerevich Popenkov \\ Moscow University of the Ministry of Internal Affairs of Russia named by V.Ya. Kikot, \\ Moscow, Russia \\ https://orcid.org/0000-0001-5582-606X \\ Dmitriy Aleksandrovich Ivanov \\ Moscow State Institute of International Relations (University) of the Ministry of Foreign Affairs \\ of the Russian Federation (MGIMO-University), Moscow, Russia \\ https://orcid.org/0000-0002-2023-3771 \\ Sergey Nikolaevich Khoryakov \\ Moscow Academy of the Investigative Committee of the Russian Federation, Moscow, Russia \\ https://orcid.org/0000-0001-7239-4924 \\ Lyudmila Nikolaevna Poselskaya \\ Moscow University of the Ministry of Internal Affairs of Russia named by V.Ya. Kikot, \\ Moscow, Russia \\ https://orcid.org/0000-0002-9213-5388
}

Received 09-08-20 Revised 10-10-20

Accepted 20-12-21 On line 03-17-21

*Correspondencia

Email: dmitriy.a.ivanov@bk.ru

(c) Universidad San Ignacio de Loyola, Vicerrectorado de Investigación, 2021. 


\section{Summary}

Authors study the issues of providing the suspect and the accused with the right for defense in criminal proceedings through the prism of the provisions enshrined in international normative legal acts and the Constitution of the Russian Federation. The relevance of this article is substantiated by the authors by the fact that the consideration of the problems of the procedural status of the suspect and the accused in the criminal case should start with this basic provision of the principle of criminal proceedings, such as ensuring the right for protection to the suspect and the accused under article 16 of the Criminal Procedure Code of the Russian Federation. In the context of the modern legal state and the requirements of the Constitution of the Russian Federation, which establishes the basic rights and freedoms of the person and the citizen. The solution to this problem becomes extremely important in the field of criminal justice, which is inevitably associated with the restriction of the constitutional rights of the individual within the limits allowed by law. In this regard, the problems of ensuring the right of the suspect and the accused to a defense require special attention. Based on the results obtained, the authors conclude that compliance with the guarantees of the right to defense of suspects and accused persons has a significant impact on the domestic and foreign policy image of the Russian Federation, being directly proportional to the legal insinuations of international organizations and attempts to influence the Russian legal system.

Keywords: Criminal Proceedings, Suspect, Accused, Right To Defense, Presumption Of Innocence, Principles Of Criminal Proceedings.

\section{Resumen}

Los autores estudian la cuestión de otorgar al sospechoso y al acusado el derecho de defensa en los procesos penales a través del prisma de las disposiciones consagradas en los actos jurídicos normativos internacionales y la Constitución de la Federación de Rusia. La pertinencia de este artículo es corroborada por los autores por el hecho de que la consideración de los problemas de la situación procesal del sospechoso y del imputado en la causa penal debe partir de esta disposición básica del principio del proceso penal, como es la garantía de la derecho a la protección del sospechoso y el acusado en virtud del artículo 16 del Código de Procedimiento Penal de la Federación de Rusia. En el contexto del estado legal moderno y los requisitos de la Constitución de la Federación de Rusia, que establece los derechos y libertades básicos de la persona y el ciudadano. La solución a este problema adquiere suma importancia en el campo de la justicia penal, que inevitablemente se asocia a la restricción de los derechos constitucionales del individuo dentro de los límites permitidos por la ley. En este sentido, los problemas de garantizar el derecho del sospechoso y del acusado a una defensa requieren una atención especial. Con base en los resultados obtenidos, los autores concluyen que el cumplimiento de las garantías del derecho a la defensa de los sospechosos y acusados tiene un impacto significativo en la imagen de política interna y exterior de la Federación de Rusia, siendo directamente proporcional a las insinuaciones jurídicas de los organismos internacionales. e intenta influir en el sistema legal ruso.

Palabras clave: proceso penal, sospechoso, imputado, derecho a la defensa, presunción de inocencia, principios del proceso penal. 


\section{Introduction}

The construction of the legal state in modern Russia is the most important task of the state. Without building legal institutions aimed at protecting human and civil rights as the highest value of modern society, it is impossible to imagine progress and modernization, economic development, and strengthening the external political authority of the Russian Federation as an independent and sovereign state.

The criminal procedure law not only establishes the right to a defense but also ensures it, so the content of the principle under consideration covers, in addition to the exercise by suspects and accused persons of their rights, also the activities of other participants in criminal proceedings to exercise these rights in order to properly resolve the case and pass a fair sentence in the future.

In the Russian Federation, this principle is based on Articles 48 and 49 of the Constitution of the Russian Federation, which in turn guarantee to a person and a citizen the right to receive qualified legal assistance, and in cases provided for by law, legal assistance is provided free of charge (Part 1 of Article 48 of the Constitution of the Russian Federation).

\section{Materials and methods}

The methodological basis of the study of the principle of providing the suspect and the accused with the right to a defense is determined by the subject of the study and is explained by the use of special legal methods.

The general scientific system method allowed us to formulate the features of ensuring the right of the suspect and the accused to defense.

The systematic approach allowed us to look at the protection of the rights of the suspect and the accused to the defense, as a broad, multidimensional, integral complex of interrelated elements of the legal system.

The historical and legal method allowed us to make an analysis of ensuring the right of the suspect and the accused to defense in the conditions of socio-political changes that took place in the domestic jurisprudence in various time periods.

The comparative legal method allowed us to study the current legislation and regulatory legal acts in the field of guarantees of the right to protection. This method made it possible to identify problems in the designated area, as well as to form an author's position and make proposals for their resolution, including improving the current criminal procedure legislation.

Through the use of methods of analysis and synthesis, real information is obtained about the effectiveness of existing measures aimed at ensuring the right of the suspect and the accused to a defense.

As the main one, the general scientific system method is used, by means of which the features of the implementation of the principle of providing the suspect and the accused with the right to defense are formulated.

\section{Results Analysis}

The right of every person subjected to criminal prosecution to defense is also a generally recognized international legal principle (Pushkarev et al., 2020, p. 331). Its provisions are proclaimed in a number of international legal acts: the Universal Declaration of Human Rights (1948) (Article 10), the International Covenant on Civil and Political Rights (1966) 
(subparagraph "d", paragraph 3, Article 14), the Convention for the Protection of Human Rights and Fundamental Freedoms $(1963 ; 1984)$ (subparagraph "c", paragraph 3, Article 6), etc.

In accordance with these acts of every person in the determination of any criminal charge against them has the right to defend himself in person or through a defender of his own choosing, and if he has no counsel, the right to be informed of this right and to have appointed counsel in any case when required by the interests of justice, donated to them when they do not have enough money to pay for the services of the defender.

It is common to allocate, as one of the essential elements of any rule of law, equality before the law, so that all citizens receive equal protection under the law, and offenders are subject to proportionate punishment, irrespective of their political, social, or economic status. A similar approach is followed by domestic legal scholars.

According to the traditional approach, the right to protection is usually understood as a set of rights provided for and secured by the criminal procedure legislation of a person who is suspected or accused of committing a criminal act in a criminal case. Currently, there are different opinions on the understanding of the right to protection.

First of all, the content of the right to protection is noted in international legal acts. The Universal Declaration of Human Rights (Déclaration Universelle des droits de l'homme), adopted in France in 1948, declares in article 7 that "all persons are equal before the law and are entitled, without distinction, to the equal protection of the law. All persons have the right to equal protection from any discrimination that violates this Declaration, and from any incitement to such discrimination" (The Universal Declaration of Human Rights, 1948).

In 1953, the Convention for the Protection of Human Rights and Fundamental Freedoms (European Convention on Human Rights) entered into force. Sub-paragraph. "c" item 3 of art. 6 of the act provides, first, the right of the defendant personally and (or) with the help of counsel, the legal representative to defend themselves against accusations or suspicions all stipulated in the criminal procedure law ways and means, and the ability to use qualified legal assistance in the implementation of their criminal prosecution, and, secondly, the duty of the court, prosecutor, investigator and inquirer, which corresponds to this right, to ensure, that is, to create real conditions for the possibility of exercising the right to defense granted to the accused (suspect) (Yakimovich, 2015, p. 151).

The provision on the right to protection is enshrined at the international level and, as a result, is recognized in the legislation of Russia.

The Constitution of the Russian Federation, adopted by popular vote in 1993, in Article 45 establishes the provision that "state protection of human and civil rights and freedoms in the Russian Federation is guaranteed, and everyone has the right to protect their rights and freedoms in all ways not prohibited by law". Article 46 states the provision that "everyone is guaranteed judicial protection of his rights and freedoms". Further, Part 1 of Article 48 of the Constitution of the Russian Federation guarantees a citizen, including a suspect and an accused, the right to receive qualified legal assistance. From these provisions, we can say that the right to state protection of rights and freedoms is the most important component of the legal status of an individual in the Russian Federation, as a democratic state governed by the rule of law.

The constitutional norm, which establishes the right of everyone to receive qualified legal assistance, has a direct effect and directly regulates public legal relations, including criminal procedure, regardless of whether or not there are legislative acts in this area (Krysina, 2017, p. 95-96). However, the legislator tried to fix such norms in the further development in the industry legislation, taking into account the specifics of regulated public relations. 
In turn, Article 16 of the Criminal Procedure Code of the Russian Federation guarantees the right to a defense, namely, the suspect and the accused are guaranteed the right to defense, which they may exercise in person or through legal assistance and (or) legal representative.

$\mathrm{V}$. Yu. Melnikov logically asserts that "the provision, implementation, and protection of human rights and freedoms is a kind of legal mechanism, which in a broad sense is understood as a socially determined, legally stipulated set of coordinated actions in order to obtain the benefit of the interested person, mediated by law (freedom). Guarantees of human rights and freedoms are an integral part of this mechanism: social conditions and special legal means. Among the latter, it is necessary to distinguish in principle the content of those that are aimed at ensuring the full exercise of rights and freedoms and that are aimed at protecting them from violations" (Mel'nikov, 2013, p. 4).

In addition, E. F. Kutsova considered the rights of the suspect and the accused to defense as an opportunity provided for and guaranteed by the criminal procedure law, used by the suspect, the accused (their legal representative and defense lawyer) in order to protect their legitimate interests (Kutsova, 2004, p. 80-84).

V. M. Savitsky argued that the right to a defense is a criminal procedure right that arises on the basis of the implementation of one of the main criminal procedure functions, belongs only to a person as an accused. This right should not be confused with the protection of the rights of legitimate interests, which is carried out by the entire system of state public measures of a law-enforcement and law-restoring nature (Savitskiy, 1996, p.223).

In contrast to these opinions, O. V. Volkolup, Yu. B. Chupilkin argue that the right to a defense takes place, even in the case when there is no accusation in the case. Accordingly, not only suspects or accused persons have the right to defense, but also victims, witnesses, specialists, experts, and other persons, if their rights are violated (Volkolup, Chupilkin, 2005, p. 96). This point of view is debatable because, in accordance with the criminal procedure law, such subjects (as witnesses, specialists, experts) are not subject to prosecution, therefore, they do not require protection from the preliminary investigation bodies and the court. On the other hand, there is the rule "where there is an accusation, there is a defense". This means that the prosecution and the defense must exist in parallel. Therefore, in such cases, it is clear that these subjects cannot be entitled to protection. However, this does not mean that a person who has not been charged does not have the right to defend their rights and legitimate interests. The right to protect their rights and interests always exists for every person and citizen, as given to them by the state at birth. However, in our opinion, this is not the right to a defense in criminal proceedings.

N. N. Neretin considered the concept of "protection" as a set of procedural actions (inaction) that are carried out personally by the suspect, the accused, which do not contradict the norms of criminal procedure legislation, aimed at protecting their rights and legitimate interests in a criminal case. It is necessary to agree with the author that for effective protection to the accused (suspect) it is necessary to explain not only their rights but also the procedure for the implementation of these rights (Neretin, 2010, p. 4).

After analyzing the various opinions of scientists about the content of the right to protection, we can agree that this right is one of the means of state protection of the rights and legitimate interests of a person and citizen guaranteed by the system of legislation. In our opinion, for a more complete understanding of the right to protection, it is necessary to be guided by such basic elements that make up its content as the legal property, the purpose, the circle of participants who ensure or pursue its implementation, the method of implementation.

The legal property of any rule of law should be understood as a set of the main distinguishing features that give it a certain character and features of implementation. The 
content of such features includes the role of the norm in legal regulation, i.e., the nature of the normative prescription and the features of its implementation (Pigolkin, 2006, p. 98).

The purpose of the right to defense is based on the purpose of criminal proceedings since it is one of the sets of principles of this branch of law. Based on this, the purpose of the right to defense in criminal proceedings is to protect the individual (suspect or accused) from illegal and unfounded charges, convictions, detention, restrictions on their rights and freedoms (Koryakina, 2015, p.20-24).

In Russia, according to Article 15 of the Code of Criminal Procedure, the functions of prosecution, defense and resolution of a criminal case are separated from each other and cannot be assigned to the same body or the same official. This means that participants in criminal proceedings in Russia can be divided into three groups, the functions of which differ from each other (Pigolkin, 2006, p. 281). In this regard, the right to protection is derived from the function of protection (Sementsov, Skrebets, 2009, p. 87), which arise, as noted by A.M. Larin and Yu. I. Stetsovsky, simultaneously with criminal prosecution (Stetsovskiy, Larin, 1998, p. 8).

If we consider this issue from the point of view of law enforcement, we should refer to the position developed by the Plenum of the Supreme Court of the Russian Federation in Resolution No. 29 of 30.06.2015 "On the practice of applying legislation by courts that en sures the right to defense in criminal proceedings", which reveals the content of the right to defense (Resolution of the Plenum of the Supreme Court of the Russian Federation No. 29, 2015).

The Supreme Court of the Russian Federation in the resolution of the Plenum defined a wide range of ways to exercise the right to defense. In particular, it is explained that the defendant's right to protection includes not only the right to be assisted by counsel, but the right to defend themselves personally, and (or) using a legal representative by all legal ways and means, including to give explanations and evidence available in respect of them suspicions or to refuse to give explanations and evidence; to object to the prosecution to testify in the charges against them or to refuse to give evidence; to present evidence; to file motions and challenges; to give explanations and evidence in their native language or the language they speak, and an interpreter free of charge, in cases where the accused is not fluent or not fluent in the language of the proceedings (Nguyen, Tran, 2020, p 121); participate in judicial proceedings at the examination of the evidence and pleadings; to pronounce the last word; bring complaints about the actions, inaction and decisions of the bodies conducting the proceedings on the case; get acquainted with the case materials in accordance with the procedure established by law. The procedural rights of the accused may not be restricted in connection with the participation in the case of his defense lawyer and (or) legal representative.

Thus, the right of the suspect and the accused to defend themselves covers several important elements at once.

First, the rights that the suspect and the accused can exercise by their own actions by presenting evidence, participating in court interrogations of other suspects and accused, victims, witnesses, and experts, filing complaints against the actions and decisions of the inquirer, the investigator, the prosecutor, and the court.

Secondly, the rights that can be exercised by them with the help of a defender and legal representative by exercising the rights and obligations of these persons.

Thirdly, the duties of the inquirer, investigator, prosecutor, and the court corresponding to the rights of the suspect or accused, the legal representative and defender (to ensure the participation of the defender, to provide, in cases prescribed by law, to review the required documents, etc.). 
Fourth, the procedural guarantees of protection, which are in force by law, even in the absence of the will of the interested parties. It is the presumption of innocence, including the burden of proof on the prosecutor and the interpretation of the doubt in favor of the accused, rules of the inadmissibility of evidence obtained in violation of the law (article 75 of the Code of Criminal Procedure), rule on the inadmissibility of the prosecution turn for the worst (article 385, 387, 405 CPC RF).

The right to defense belongs not only to the accused and the suspect, who are officially recognized in this procedural status, but also to any person against whom actions are committed in the course of criminal prosecution (interrogated as a witness, but according to the circumstances of their participation in the commission of a crime, a search is conducted in their home, etc.).

If we talk about the international basic principles of ensuring the rights of suspects and accused persons, the Foundation of criminal procedural law is the Constitution of the Russian Federation, a model for which, in 1993, was the French Constitution, already absorbed the basic elements of protection of the rights and freedoms of man and citizen.

In international normative regulation, it is considered to be the cornerstone of such norms as the Universal Declaration of Human Rights, adopted by the Gen. Convention for the Protection of Human Rights and Fundamental Freedoms, concluded on 04.11.1950 in Rome; International Covenant on Civil and Political Rights, 1966.

Of course, today it is impossible to imagine the construction of a legal system of a civilized state, without taking into account the provisions of the above-mentioned international covenants and conventions.

\section{Conclusion}

The equality of all persons before the law is a priority of state-building, providing identical scope of the rights and obligations of the prosecution of persons subject to charges. Only the maintenance of such a balance will prevent the legal system from distortion in one direction or another, allowing us to ensure democratic principles on the scale of the state. At the same time, compliance with the guarantees of ensuring the right to defense of suspects and accused persons has a significant impact on the internal and external political image of the Russian Federation, being directly proportional to the legal insinuations of international organizations and attempts to influence the Russian legal system.

\section{References}

Koryakina, Z.I. (2015). Teoreticheskaya i normativnaya osnova prava na zashchitu v ugolovnom sudoproizvodstve rossiyskoy federatsii. Yevraziyskaya advokatura, 3: 20-24.

Krysina, N.R. (2017). Konstitutsionnyy printsip obespecheniya prava na polucheniye kvalifitsirovannoy yuridicheskoy pomoshchi $\mathrm{v}$ rossiyskom ugolovnom sudoproizvodstve. Pravovaya politika i pravovaya zhizn', 2: 91-96.

Kutsova, E.F. (2004). Nekotoryye voprosy obespecheniya prav i zakonnykh interesov lichnosti po UPK RF. Moscow.

Mel'nikov, V.Yu. (2013). Neobkhodimost' sozdaniya mekhanizma obespecheniya, realizatsii i zashchity prav cheloveka v ugolovnom sudoproizvodstve. Advokatskaya praktika, 2: 4-8.

Neretin, N.N. (2010). Pravo na samostoyatel'nuyu zashchitu podozrevayemogo, obvinyayemogo $\mathrm{v}$ dosudebnom proizvodstve: avtoref. ... kand. yurid. nauk. Krasnodar. 
Nguyen, T.L.H., Tran, V.T. (2020). Criminal prosecution of persons who do not speak the language of criminal process. Revista Inclusiones, 7 Especial: 121-125.

Pigolkin, A.S. (2006). Teoriya gosudarstva i prava. Moscow: Gorodets.

Protocol No. 4 to The Convention for the Protection of Human Rights and Fundamental Freedoms. (1963). Retrieved from: http://base.garant.ru/2540803/

Protocol No. 7 to The Convention for the Protection of Human Rights and Fundamental Freedoms. (1984). Retrieved from: http://www.consultant.ru/document/cons_doc_LAW_29158/

Pushkarev, V.V., Artemova, V.V., Ermakov, S.V., Alimamedov, E.N., Popenkov, A.V. (2020). Criminal prosecution of persons, who committed criminal, acts using the cryptocurrency in the Russian Federation. Revista San Gregorio, 42: 330-335.

Pushkarev, V.V., Trishkina, E.A., Tokareva, E.V., Cuong, B.T., Shepeleva, O.R. (2020). The adversarial approach in the pretrial phase of prosecution. Cuestiones Políticas. 37(65): 281-287.

Resolution of the Constitutional Court of the Russian Federation No. 30-P. (November 21, 2017). On the case of checking the constitutionality of the provisions of Articles 38 and 125 of the Criminal Procedure Code of the Russian Federation in connection with the complaint of citizen V.V. Chensky. Retrieved from: http://cpk42.com

Resolution of the Plenum of the Supreme Court of the Russian Federation No. 29. (June 30, 2015). "On the practice of the courts' application of legislation providing the right to defense in criminal proceedings". Retrieved from: https://rg.ru/2015/07/10/verhovniy-sud-dok.html

Savitskiy, V.M. (1996). Sudebnyy kontrol' i prava cheloveka. Moscow: Izdatel'stvo: prava cheloveka.

Sementsov, B.A., Skrebets, G.G. (2009). Uchastiye advokata-zashchitnika v formirovanii dokazatel'stv na stadii predvaritel'nogo rassledovaniya. Moscow: Yurlitinform.

The International Covenant on Civil and Political Rights (ICCPR). (1966). Retrieved from: http://www.consultant.ru/document/cons_doc_LAW_5531/

The Universal Declaration of Human Rights. (1948). Retrieved from: http://www.consultant.ru/document/cons_doc_LAW_120805/

Volkolup, O.V., Chupilkin, Yu.B. (2005). Garantii prav uchastnikov ugolovnogo sudoproizvodstva Rossiyskoy Federatsii. Krasnodar: Kubanskiy gosudarstvennyy universitet. 